\title{
Emotional Labour, Self Efficacy and Service Orientation Behaviour: A Study of Selected Hotels in South Nigeria
}

\author{
Polycarp Igbojekwe (Ph.D)
}

Department of Hospitality and Tourism Management Imo State University, Owerri, Nigeria

\begin{abstract}
The main objectives of this study were to investigate the extent of emotional labour self-efficacy, customer-service orientation behaviour and job knowledge possessed by customer-contact employees with a view to predicting the overall quality of interaction between service employees and customers to the hotels under study. Data were gathered through questionnaire. Formulated hypotheses were tested using correlation methods, and Z-test for tests of significance. Analysis revealed that emotional labour dimensions (SA, DA) were found to have significant relationship with service-orientation behaviour. In the 1 to 3-star hotels self efficacy, job knowledge and service-orientation behavior were found to be low and below average. The study revealed a positive relationship between self efficacy and service orientation behaviour. In all the variables, service employees of the 5-star were rated higher than the others. Based on above findings, it is predicted that the quality of customer experiences in these hotels is below expectation. We therefore recommend that hotel organizations should re-examine and redesign their internal marketing and human resources practices to enhance self efficacy and job knowledge.
\end{abstract}

Keywords: Customer service; Job knowledge; Self efficacy, Service orientation behaviour

\section{BACKGROUND OF THE STUDY}

To cope with the rising competition, and changing taste of consumers, industry operators need to continue to strategize. In such business environment, successfully satisfying customers' needs and wants requires humanist aspect of high standard. A hotel organization can satisfy its customers by differentiating its service delivery by designing a superior delivery process through its interactive workers who are the most important resources or assets in their endeavour to provide excellent service and exceed customer expectations, achieve competitive advantage and exceptional organizational performance, (Kotler, Bowen and Makens, 2006; Power, 1992).

Hotel which is a core sector of the hospitality industry, being service intensive, is a unique industry because of the characteristics of service which include intangibility, inseparability, variability and perishability. Among these characteristics, inseparability is the one that is mostly associated with emotional labour. Inseparability entails that both the service provider and the customer must have contact (point-of-encounter or 'moment-of-truth') for transactions to occur and that service is produced and consumed simultaneously. Therefore, the quality of service delivered cannot be separated from the quality (or personality) of the service provider. The behaviour of the customercontact employee is a critical part of the product for which the customer pays (Kotler et al, 2006; Power, 1992; Zeithaml, Parasuraman, and Berry, 1990), as it influences the interaction between the service provider and customer. In services, consumer satisfaction is influenced by the quality of the interpersonal interaction (Bitner, Booms, and Mohr, 1999, Gummenson, 2004) as service is produced jointly.

In the hotel industry, service is a deed and it happens to somebody (customer or guest), the manager does not have the time or opportunity to inspect, shade away, and discard and/or recall defective products before customers receive them. For this reason, organizations should pursue a zero-defect service goal. A 'zero defect' service is service promptly delivered right first time around and each time (Power, 1992). Meeting such service delivery goal requires an appropriate organizational climate, and having employees who possess technical skill, interpersonal, emotive work and communication skills. Such employees should possess personality attributes such as emotional 
intelligence and emotional self-efficacy in order to perform effectively.. This also requires that the organization must be customer-centric and the service employees must possess adequate job knowledge, exhibit service orientation behaviours at every point of encounter with customers.

Emotional labour was coined and popularized by Hochschild. (1983) Hochschild defines the term to mean "the management of feeling to create a publicly observable facial and bodily display" intended to produce a particular state of mind in others; emotional labour is sold for a wage and therefore, has exchange value". Ashforth and Humphrey (1993) define emotional labour in behavioural terms as the act of displaying the appropriate emotion with the goal to engage in a form of impression management for the organization. Morris and Feldman (1996) also define emotional labour as the act of expressing organizational desired emotions during service transactions.

Self-efficacy is the belief that one can perform adequately in a situation (Gibson et al, 1994). People's sense of capability influences their perception, motivation and performance. Individuals with high level of efficacy would cope better with emotional labour stress than those with low self-efficacy (Ashforth and Humphrey, 1993). Individuals with high self-efficacy cope better with stress than those with low-self-efficacy (Leiter, 1992). Adeyemo and Ogunyemi (2008) found that self-efficacy is a potent predictor of occupational stress, that self-efficacy has negative relationship with occupational stress.

Service orientation relates to the behaviours of employees performing service roles (Gwinner, Bitner, Brown and Kumar (2005). Cran (1994) defines service orientation as the behaviours of employees that affect the quality of the interaction between the staff and customer of an organization. Service orientation has been found to have positive influence upon overall quality of service delivery, (Jayawardhena, 2000; Cran, 1994; Hogan, Hogan and Busch, 1984). In the service industry, employees' behaviour at the points of encounter (moments of truth) is a critical factor in determining customers' perception of service quality (Bitner et al 1990). During the service encounter, or 'moment of truth', the formation of customer's perceptions is often more largely based upon the emotional and intangible content of the encounter than on surroundings (Jayawandhena, Farrell and Sharma (2007); Susskind, Kalmar and Borchgrevink (2003). Therefore, the personal contact that takes place must be of superior quality, and the service employee must involve his/her feelings in the situation.

Hochschild (1983) suggestions generated the attention of later researchers who actually confirmed that emotional labour has some negative consequences on service workers. Guy et al (2008) report that emotional exhaustion (burnout), cynicism, and ineffectiveness was present in their study participants. Grandey (2000; Brotheridge and Grandey 2003) all report that surface acting has been linked to negative psychological and physical health outcomes including burnout in the form of increased emotional exhaustion, depersonalization, reduced personal accomplishment, job dissatisfaction, depression, anxiety, psychosomatic complaints and intention to resign. Burnout can lead to deterioration in the quality of service provided and appears to be a contributor to turnover, absenteeism and low morale (Provis et al, 2003; Morris and Feldman, 1997; Zapf Vogt, 1999; Maslach and Jackson, 1981). Given the negative effects associated with the performance of emotional labour, it is imperative that service employees are able to cope with the demands associated with the performance of such labour, so that their well-being is not affected and subsequent interactions with customers are not tarnished.

Emotional labour involves attempts to align privately felt emotions with normative expectation or to bring the outward expression of emotion in line with them. Hochschild (1983), refers to the first process as "deep acting" and the second as "surface acting" aiming to convey the fact that the first involves an attempt to change what is privately felt, while the second focuses on what is publicly, facially and bodily displayed in order to create a particular emotion state in another person.

Hochschild (1983) sees emotional labour as increasingly relevant in the service industry given the particular demands of service job. Service jobs depend heavily on workers' ability to manage their emotions, service employees have sought to control this process, thereby transforming emotion management into labour as formal job requirement.

In the hotel industry, either failure to display the required emotions (display rules) or feeling uneasy about showing the approved emotions, can ultimately lead to poor quality service. In effect, the failure to manage the emotional labour of employees can and does lead to a loss of competitive advantage of the organization. It can lead to economic failure of a firm. 


\subsection{Statement of the Problem}

Increasingly companies are realizing that emotion regulation during employee-customer interaction is the core of a service experience that influences customers' perception of service quality that leads to satisfaction or dissatisfaction (Chu, 2002). As the role of emotion is gaining attention as a central element in service quality management, researches on the effects of emotions on satisfaction with service quality are being conducted. Recent studies suggest that emotion is a fundamental attribute in satisfaction and that customer's satisfaction should include a separate emotional component (Wong, 2004; Wang and Boles, 2010).

Research evidence shows that dissatisfaction with service encounters can lead to an array of behaviours that have negative impact on organization particularly its bottom-line (Kennedy, 2008). According to Lee (2010) emerging research on customer loyalty shows that an organization's success is closely linked to its ability to create the kind of exceptional customer service experience that leads to repeat business.

Customer service research shows that $68 \%$ of customers defect from a firm because they were treated with an attitude of indifference (Lee, 2010). Thus, 68\% of what leads to customer defection is related to emotion - or in this case, the lack of emotion. The connection between emotional labour and customer service is obvious, thus the economic consequences of not addressing customer-contact employees' emotions can be disastrous to an organization. Emotional labour is therefore at the heart of service, and quality service is the lifeblood of the hospitality industry (Davidoff, 1994; Enz and Siguaw, 2000; Johnson, 2004).

Service jobs depend heavily on workers' ability to manage their emotions and that of others (Wharton, 2009; Kruml and Geddes, 2000; Wu and Yuan, 2012). This ability to manage one's emotion requires that the service provider should possess appropriate personality and self efficacy should be one of them. Self efficacy is a potent predictor of job satisfaction (Ashforth and Humphrey, 1993); performance (Guy et al, 2008) and resilience to stressful job (Bandura, 2000; Leiter, 1992; Adeyemo and Ogunyemi 2008). Self efficacy entails that the employee should be able to selfappraise the emotional climate, be self monitoring, possess adequate job knowledge and act appropriately. Performance of emotional labour poses a serious challenge to service workers. Part of the challenge is that service workers must often conceal their real emotions when guests give them a hard time, and they must continue to smile through negative feedback from guests (Chu and Murrmann, 2004); the worker must handle the situation in the absence of his supervisor and without any assistance from him at the points of interaction. The implication of the above on service providers is that they must possess high level of emotional self-efficacy.

Research evidence suggests that individual's dispositions act as antecedents of emotional labour therefore, influence how individuals perform emotional labour, and its associated consequences (Hochschild, 1983; Weiss and Cropanzano, 1996; Chu, 2002; (Grandey, 2000). Employee understanding of his job contents and its importance will influence how he performs his job. It is against this background that the researcher embarked on this study to examine the extent of emotional labour job knowledge, self efficacy, and service orientation behaviour of service employees with a view to predicting the overall quality of interaction between service employees and customers to the hotels under study. Understanding of the attitudes and behaviours of service workers towards their work and customers will help management come to terms with the overall experiences their customers have with their employees they deal with on any transaction.

\subsection{Objectives of the Study}

The major objectives of this study were to find out the level of emotional labour self- efficacy, and job knowledge possessed by customer-contact employees.

In the course of this study we also made attempts to find out;

$>$ Extent of service orientation behaviour of customer-contact employees,

$>$ Relationship between surface acting and service orientation behaviour

$>$ Relationship between deep acting and service orientation behaviour,

$>$ Relationship between self-efficacy and service orientation behaviour. 


\subsection{Statement of the Hypotheses}

Based on the objectives of the study, the following hypotheses stated in null (Ho) were formulated to guide the study:

$>$ The level of (perceived) self efficacy possessed by customer-contact employees is

$>$ low /unsatisfactory.

$>$ The level of emotional labour (perceived) job knowledge possessed by customer-contact employees is low /inadequate.

$>$ Extent of service orientation behaviour of customer-contact employees is low /unsatisfactory.

$>$ There is no significant relationship between surface acting and service orientation behaviour of customer-contact employees

$>$ There is no significant relationship between deep acting and service orientation behaviour,

$>$ There is no significant relationship between self-efficacy and service orientation behaviour.

\section{BRIEF REVIEW OF RELATED LITERATURE}

This sub-section presents a brief review of the study variables.

\subsection{Self-Efficacy}

Efficacy is belief Self- that one can perform adequately in a situation. People's sense of capability influences their perception, motivation and performance (Gibson et al, 1994). The When individuals acquire an internal control orientation that leads them to set goals and develop action plans to generally accomplish them, they develop a sense of self-efficacy. Such individuals believe they are masters of their own destiny, and they make things happen rather than react to events. They exercise influence over events that affect their lives.

A strong self-efficacy enhances human performance and personal well-being (Bandura, 2000). For instance, people with high assurance in their capabilities approach difficult tasks as challenges to be mastered rather than as threats to be avoided. They face threatening situations with assurance that they can exercise control over them. Such an efficacious outlook produces personal accomplishment, reduces stress and lowers vulnerability to depression (Bandura, 2000). Efficacy beliefs influence the amount of stress and anxiety individuals experience as they engage in an activity (Pajare, 1994). Individuals with high self-efficacy cope better with stress than those with low-self-efficacy. Adeyemo and Ogunyemi (2008) found that self-efficacy is a potent predictor of occupational stress, that selfefficacy has negative relationship with occupational stress. Guy et al (2008) conducted their studies to assess the potency of emotion work forms and the relationships of emotion work, self-efficacy, job satisfaction and burnout, and report that self-efficacy is the most potent influence on job satisfaction. Ashforth and Humphrey (1993) suggest that emotional labour may increase self-efficacy; and selfefficacy influences task effectiveness. Individuals with high level of efficacy would cope better with emotional labour stress than those with low self-efficacy.

Emotional self efficacy entails that the individual must exhibit self-awareness. Self-awareness is bound and positively associated with self-control (Rahim and Psenicka, 2002). These authorities define self-control as the ability of keeping own emotions under control, and moreover to keep calm under potentially conflict relations; for example a customer who shows anger or uneasy and who becomes over demanding in his expressions. In this circumstance, the service employee is expected to remain calm in order not to aggravate the situation (Cavelzani, Esposito and Villamira, 2009).

Emotional self-efficacy also entails the appraisal and expression of emotion in the self The concerns an individual's ability to recognize and express his emotions; individuals high on this dimension are more easily aware of their emotions than the average person.

Emotional self efficacy entails self-monitoring. Self-monitoring refers to the extent to which people monitor, control and modify their expressive behaviour to meet standards of social appropriateness (Snyder, 1974). High self-monitors are more willing and able to change their own emotional expression to fit the situation than low-self monitors. High self-monitors are more aware of their emotional cues and of others. Research has indicated that high self-monitors pay more attention to situational cues about which emotions are appropriate, and also are more skilled at presenting 
emotions (Snyder, 1974, Riggio and Friedman, 1982). Low self-monitors tend to remain "true" to their internal feelings (Grandey, 2000). In jobs where emotional labour is required, low self-monitors should have a more difficult time complying with display rules. The inclination of the high selfmonitors to comply with organizational display norms may result in less dissatisfaction with the emotional labour part of their jobs and the ability to regulate their expressive emotion. They may be more satisfied with the emotional labour component of their job because it rewards them for behaviour in which they normally engage. Conversely, low self-monitors may be more prone to emotional exhaustion than other workers who perform emotional labour, because their expressive behaviour is guided more by their affective state rather than as desire to comply with social standards, therefore to obey display rules they may have to engage in more effortful deep acting (Wharton, 1993).

Recent research has shown that low self-monitors may report high levels of emotional labour and higher levels of stress in customer service jobs. Studies suggest that high self-monitors would be less reactive to dissonance (Abraham, 1998) and better at customer service job (Caldwell and O'Reilly, 1982; Friedman and Miller-Herringer, 1991). Wharton (1993) found that high self-monitors in emotional labour jobs, were less likely to report burnout than low self-monitors.

High-self-monitoring people will demonstrate more cross-situational variability in behaviour than people who are low in self-monitoring (Spiro and Weitz, 1990). A positive relationship has been found between self-monitoring and customer-orientation behaviour (Spiro and Weitz, 1990; Noor and Muhamad, 2005). Based on the above findings, self-monitoring is argued to be an important personality trait for employees performing emotional labour. Sales people with high self-monitoring trait have higher tendency to develop relationship with customers and are perceived to be more able to tailor their personality to any particular situation than low self-monitors. This allows high selfmonitors to display appropriate emotion as demanded by the situation. Employees performing emotional labour are expected to monitor situations closely, adjust and act accordingly in order to meet customers' needs.

\subsection{Service Orientation Behaviour of Service Employees}

Service orientation as a concept is taken at two perspectives; an organizational level and individual level. At an organizational level, service orientation appears to be more of a strategic business philosophy (Yoon et al, 2007). At an individual level, service orientation relates to the serice orientation behaviours of employees performing service roles (Gwinner, Bitner, Brown and Kumar, 2005; Wing et al, 2010). Cran (1994) defines service orientation as the behaviours of employees that affect the quality of the interaction between the staff and customer of an organization. Service orientation has been found to have positive influence upon overall quality of service delivery, (Jayawardhena, 2000; Cran, 1994; Hogan, Hogan and Busch, 1984).

Researchers suggest that service oriented employees are more inclined to perform service enhancing behaviour during service encounters with customers. Service orientation behaviour of service employees appears to be at the heart of delivering customized, quality service (Gwinner et al, 2005; Hennig-Tharau (2004).The implication of the above is that the behaviour of service employee at 'moment of truth' is critical in determining the quality of the encounter, customer's emotional satisfaction and the overall quality of service rendered. It therefore, becomes crucial that service employee manages his/her emotio $\mathrm{s}$ at the point of encounter in order not to create negative impression of the organization.

\section{RESEARCH Methodology}

This section presents the methods used in the study. The study was a descriptive research; hence, a survey method was adopted. Descriptive data are typically collected through a questionnaire, an interview, observation (Gay, 1996) and recorded events and documents.

\subsection{Population of the Study and Sampling Procedure}

The population for the study comprised of customer service staff of hotel establishments in the SouthEastern zone. Hotels of one (1) to five (5) star classification were used in this study. A total of thirty one (31) hotels were selected for the study. The total population was 441. 
A non-probability sampling method was adopted in choosing the establishments for the study. Stratified sampling was used to determine individual company's sample size. By applying the stratified method, and using the Bouley's (1964) population allocation formula given by Okeke (1995) we determined sample size for each hotel. Random sampling method was used to select the customer-contact employees. Respondents consisted of male and female staff that have at least two years work experience in the industry. The Taro Yamane's formula given by Ogbuoshi (2006) was used to determine the sample size from each hotel. Applying this formula, sample sizes for customercontact employees was 210 .

\subsection{Data Collection Instrument and Administration}

Primary data were collected through structured questionnaires and oral interview. The Likert-type scales were used. Response options applied were strongly agrees (SA); agree (A); disagree (D), or strongly disagree (SD), never (0), rarely (1); sometimes (2); often (3), and always (4). Each response was associated with a point value and an individual's score was determined by summing the point values for each point value; 4, 3, 2, 1 and 0 were assigned to always, often, sometimes, rarely and never respectively where appropriate to positive responses to positive statements. For negative statements the point values were reversed, always was assigned zero (0).

\subsection{Designing the Research Instrument}

In this study some already developed, pre-validated and reliable scales were adapted in addition to scales developed by conducting pilot studies and extensive literature search. Attitude statements for the study were generated through in-depth interviews and discussions with the operators of the industry and lecturers in the field of hospitality. Validity and reliability tests were conducted for the modified scales. The questionnaires were designed following procedure described by Hall (2010). The questionnaire is presented in the Appendix. The Cronbach's alpha coefficient for internal consistency was used to determine reliability of the research instrument. Procedures described by Gliem and Gliem (2003) and Onunkwo (2002) were adopted

Emotional labour scale developed by Brotheridge and Lee (1998) was used. The scale is composed of sub-scales that measure dimensions of emotional labour -the surface acting (SA), deep acting (DA), and emotional dissonance. Brotheridge and Lee (2002) report high coefficient alpha for DA and SA sub-scales as .89 and .80 respectively. Naring, Briet and Brouwers (2007) report alpha coefficient of .79 and .81 for SA and DA respectively. Groth et al (2009) report alpha coefficient of .90 and .92 for DA and SA respectively. Reliability coefficient (Cronbach's alpha) for self efficacy, service orientation behaviour and perceived job knowledge were $0.84,0.84$, and 0.87 respectively.

\subsubsection{Emotional Labour Self Efficacy}

To construct this scale, three sample items were derived from Guy et al's (2008) emotional labour personal efficacy scale with five items and Cronbach's alpha value of .883. Some other questions in the study for personal efficacy sub-scale were generated through literature search and discussion with employees of the hotels selected for the pilot study. This scale has reliability coefficient alpha of .84 . In this scale, score of a one corresponds to strongly disagree and 4 corresponds to strongly agree, therefore, high scores suggest high level of personal efficacy.

\subsubsection{Customer-Service Orientation Behaviour Sub-Scale}

This sub-scale measured the perception, attitudes and behaviour towards service, and customers particularly at the "moment of truth" or point of encounter. This scale has a score of one corresponding to strongly disagree and four corresponding to strongly agree except where the question was negative. Items were drawn from validated and reliable scale developed by Peccei and Rosenthal (2001) which has internal reliability coefficient alpha value of .80. The customer-service orientation behaviour scale constructed for this study has reliability coefficient of .83 .

\section{Data Analysis AND Results}

Descriptive statistics for the study variables were determined. This involved calculating mean scores, mode, and standard deviation for each attitude statement and sub-scales. Hypotheses were tested using Z-test, Pearson product moment and Spearman's rho corellation models. 


\subsection{Questionnaire Return Rates of Study Respondents are Presented in Tables 4.1.}

The profile of the study respondents indicated that for the customer service workers, $45.2 \%$ were males, while $54.80 \%$ were females. There ages range from 20 years and above. $22.37 \%$ of the respondents specialized in catering and hotel management. The job tenure for hotel employees ranges from 2 years and above at customer contact positions. For the analyses, the key was thus presented: Key: $0=$ Not Applicable (NA) (or has no place in service delivery); $1=$ Strongly Disagree (SD) (or Rarely); 2 = Disagree (D) (or Sometimes); 3 = Agree (A) (or Often) ; $4=$ Strongly Agree (SA) (or Always); and mean score below 2.5 does not meet expectation.

Table4.1. Questionnaire Return Rate

\begin{tabular}{|l|l|l|}
\hline & Customer Service Workers \\
\hline Hotel Grades (Star) & Distributed & Returned \\
\hline 1 & 48 & $38(79 \%)$ \\
\hline 2 & 54 & $42(77.78 \%)$ \\
\hline 3 & 58 & $46(79.3 \%)$ \\
\hline 4 & 56 & $48(85.7 \%)$ \\
\hline 5 & 57 & $45(79 \%)$ \\
\hline Total & 273 & $219(80.2 \%)$ \\
\hline
\end{tabular}

Source: Survey data 2015

Data presented in Table 4.2 indicate the mean score for all classes which ranges from 2.0 to 2.39. The modes for 4 and 5-star stood at 3 each. Each of 1, 2, and 3-star classes has a mode of 1 . No hotel class has a mean score up to 2.5 (expected mean). Generally self efficacy in all the classes is low; however, it is lowest in the 1-star class.

Table4.2. Responses for EL Self Efficacy

\begin{tabular}{|l|l|l|l|l|}
\hline & & \multicolumn{3}{|c|}{ EL Personal Efficacy } \\
\hline Hotel Grades (Star) & Sample Size (n) & Mean & SD & MODE \\
\hline Overall & 219 & 2.18 & .66 & 1 \\
\hline 1 & 38 & 2.0 & .66 & 1 \\
\hline 2 & 42 & 2.10 & .68 & 1 \\
\hline 3 & 46 & 2.12 & .68 & 1 \\
\hline 4 & 48 & 2.24 & .62 & 3 \\
\hline 5 & 45 & 2.39 & .62 & 3 \\
\hline
\end{tabular}

Source: Survey data 2015

As observed from Table 4.3, the mean score for all classes of hotel ranges from 1.44 (for 1-star) to 2.35 (5-star) 2. The mode is 2 for all the hotel grades. By implication of the above analysis,the majority of the service employees sometimes exhibit customer service orientation behaviour. Analyses were made to determine the extent or frequency with which the customer contact employees exhibit customer oriented attitudes and behaviours during service encounter with their customers. As observed, the frequency for exhibition of customer service oriented behaviour is highest in the 5-star hotel class (39\%), and lowest in the 1-star hotel class (1\%). For all the classes, the disagree option has the highest frequency ranging from $52.2 \%$ to $64.3 \%$.

Table4.3. Responses for Customer Service Orientation Behaviour of Service Employees.

\begin{tabular}{|l|l|l|l|l|}
\hline & \multicolumn{4}{|l|}{ Service Orientation Behaviour } \\
\hline Hotel Grades (Star) & Sample Size (n) & MEAN & SD & MODE \\
\hline Overall & 219 & 2.08 & .70 & 2 \\
\hline 1 & 38 & 1.44 & .68 & 2 \\
\hline 2 & 42 & 2.12 & .67 & 2 \\
\hline 3 & 46 & 2.13 & .60 & 2 \\
\hline 4 & 48 & 2.25 & .64 & 2 \\
\hline 5 & 45 & 2.40 & .61 & 2 \\
\hline
\end{tabular}

Source: survey data 2015

Descriptive statistics for use of surface acting as strategy are presented in Table 4.4. The mean score and mode for 1-star were 3.45 and 3 respectively, meaning that the employees use surface acting often times during service interaction. As observed from the Table 4.4 service workers in the 1-star hotels use surface acting much more frequently than others. While those in the 5-star use it less frequently 
than others. The overall mean, standard deviation and mode were 2.82, 0.70 and 3 respectively. This result indicates that often times the employees use surface acting as emotional labour coping strategy.

Table4.4. Statistics for use of Surface Acting and Deep Acting as Strategies.

\begin{tabular}{|l|l|l|l|l|l|l|l|}
\hline & \multicolumn{3}{|l|}{ Surface Acting } & \multicolumn{3}{l|}{ Deep Acting } \\
\hline Hotel Grades (Star) & Sample Size (n) & Mean & Std. Dev. & Mode & Mean & SD & Mode \\
\hline Overall & 219 & 2.82 & .70 & 3 & 2.14 & .60 & 2 \\
\hline 1 & 38 & 3.45 & .52 & 3 & 1.68 & .50 & 2 \\
\hline 2 & 42 & 3.29 & .50 & 3 & 1.87 & .50 & 2 \\
\hline 3 & 46 & 2.90 & .57 & 3 & 2.09 & .56 & 2 \\
\hline 4 & 48 & 2.5 & .50 & 3 & 2.44 & .54 & 2 \\
\hline 5 & 45 & 2.11 & .53 & 2 & 2.53 & .47 & 3 \\
\hline
\end{tabular}

Source: Survey data 2015

Table 4.4 also presents descriptive statistics for use of deep acting by service employees as emotional labour coping strategy. For the 1, 2 and 3-star hotels, ( mean = 1.68, 1.87 and 2.09 respectively, and mode $=2$ ) the implication is that their employees sometimes use deep acting as strategy for managing emotional labour during service encounters. For the 4-star $($ mean $=2.44)$ and 5 -star hotels (mean = 2.53 ), indicate that their service employees often times use deep acting during service encounters.

Table 4.5 presents descriptive statistics for perceived job knowledge. The means for 1, 2 and 3-star hotels were 1.71, 2.10 and 2.24 respectively. These results indicate that1, 2, and 3-star hotels' job possess moderate level of job knowledge. Only 5-star hotel employees' mean score was up to 2.5 (expected mean) which suggests average level of job knowledge. However, the overall mean of 2.19 suggests that the employees moderately possess job knowledge.

Table4.5. Statistics for perceived emotional labour Job Knowledge

\begin{tabular}{|l|l|l|l|l|}
\hline Hotel Grade & Sample Size & Mean & Std. Deviation & Mode \\
\hline Star $)$ & $(\mathrm{n})$ & $(\mathrm{X})$ & $(\mathrm{SD})$ & $(\mathrm{M})$ \\
\hline 1 & 38 & 1.71 & .6 & 2 \\
\hline 2 & 42 & 2.10 & .58 & 2 \\
\hline 3 & 46 & 2.24 & .60 & 2 \\
\hline 4 & 48 & 2.36 & .56 & 2 \\
\hline 5 & 45 & 2.5 & .52 & 3 \\
\hline Overall & 219 & 2.19 & .61 & 2 \\
\hline
\end{tabular}

Source: Survey data 2015

\subsection{Test of Hypotheses}

Hypotheses stated earlier were tested using Z-test for hypotheses 1, 2, and 3while hypothesis 4 and 5 were tested using Pearson Product moment correlation model, and 6 was tested using Spearman's rho correlation model. Tests of significance were conducted. Table 4.6 presents summary of the outcome of hypotheses testing and decisions taken. Differences were observed from one grade of hotel to another. The 4 and 5-star hotels were rated better than 1,2 and 3-star hotels in all the variables studied in this research.

Table4.6. Summary of Hypotheses Testing and Decisions

\begin{tabular}{|c|c|c|c|}
\hline & Hypotheses as Stated & Decisions & Relationship direction \\
\hline 1 & $\begin{array}{l}\text { The level of self efficacy possessed by customer- } \\
\text { contact employees is low / unsatisfactory. }\end{array}$ & $\begin{array}{l}\text { Accept } \mathrm{H}_{0} \text { for } 1-4 \text { star. } \\
\text { Reject } \mathrm{H}_{0} \text { for } 5 \text {-star }\end{array}$ & --- \\
\hline 2 & $\begin{array}{l}\text { The level of emotional labour (perceived) job } \\
\text { knowledge possessed by customer-contact employees } \\
\text { is low /inadequate }\end{array}$ & $\begin{array}{l}\text { Accept } \mathrm{H}_{0} \text { for } 1-4 \text { star. } \\
\text { Reject } \mathrm{H}_{0} \text { for 5-star }\end{array}$ & ---- \\
\hline 3 & $\begin{array}{l}\text { Extent of service orientation behaviour of customer- } \\
\text { contact employees is low /unsatisfactory. }\end{array}$ & $\begin{array}{l}\text { Accept } \mathrm{H}_{0} \text { for } 1-4 \text { star. } \\
\text { Reject } \mathrm{H}_{0} \text { for } 5 \text {-star }\end{array}$ & ----- \\
\hline 4 & $\begin{array}{l}\text { There is no significant relationship between surface } \\
\text { acting and service orientation behaviour of customer- } \\
\text { contact employees }\end{array}$ & Reject hypothesis & $\begin{array}{lll}\begin{array}{l}\text { Negative } \\
\text { correlate }\end{array} \quad \text { (r) } & \text { Pearson } \\
0.432 . & & \\
\end{array}$ \\
\hline 5 & $\begin{array}{l}\text { There is no significant relationship between deep } \\
\text { acting and service orientation behaviour, }\end{array}$ & Reject hypothesis & $\begin{array}{l}\text { Positive. Pearson } \\
\text { correlate (r) was } 0.295 .\end{array}$ \\
\hline 6 & $\begin{array}{l}\text { There is no significant relationship between self- } \\
\text { efficacy and service orientation behaviour. }\end{array}$ & Reject Hypothesis & $\begin{array}{l}\text { Spearman's } \quad \text { rho }= \\
.407 * * \text { Positive. }\end{array}$ \\
\hline
\end{tabular}

Source: Survey data 2015

Key: ** means that correlation is significant at 0.01 level (2 tailed). 
Table 4.6 shows that surface acting does have a negative and weak influence on employees' service orientation behavior as our Pearson correlate (r) was -0.432. Coefficient of determination $\left(\mathrm{r}^{2}\right)$ multiplied by 100 gives $18.7 \%$. While deep acting does have a positive and weak influence on employees' service orientation behavior as our Pearson correlate (r) was 0.295. Coefficient of determination $\left(r^{2}\right)$ multiplied by 100 gives $8.7 \%$.

\subsection{Discussion and Implications of Findings}

The two main objectives of this study were to find out the levels of emotional labour self- efficacy, and job knowledge possessed by customer-contact employees. In this regard, majority of the workers possess self efficacy and job knowledge below average person; particularly in 1-4 star hotels. Their levels do not meet expectation, implying that their performances as service providers in their various hotels are likely not to meet organizational goals. Low self efficacy entails low self awareness and low self monitoring which are associated with ineffectiveness in the performance of emotional labour (Caldwell and O'Reilly, 1982; Friedman and Miller-Herringer, 1991; Abraham, 1998).

Research evidence suggests that job knowledge is a potent predictor of job performance (Mullins, 2005), and self efficacy level is a potent predictor of resilience to (emotional labour) stress ((Leiter, 1992; Adeyemo and Ogunyemi (2008; Guy et al, 2008; task effectiveness and job satisfaction (Ashforth and Humphrey, (1993). Service employees with low self efficacy are vulnerable to occupational stress (Pajare, 1994; Bandura, 2000; Wharton,1993). Low job knowledge and emotional labour stress are detrimental to service quality. These findings are of significance to hotel organizations as emotional stress can lead to deterioration of service quality because of the amount of effort it takes to maintain a smiling face by service providers while coping with difficult customers who believe that they are always right.

The relationships of surface acting (SA) and deep acting (DA) with service orientation behaviour of service employees were investigated. SA was found to have negative relationship with service orientation, while DA has positive relationship with service orientation behaviour. satisfaction. These findings are consistent with pervious empirical studies (i.e. Morris and Feldman, 1997; Grandey, 1999, Kruml \& Geddes, 2000, Yalcin, 2010, Wharton, 1993). Service orientation behaviour has been found to have positive influence upon overall quality service delivery, (Jayawardhena, 2000; Cran, 1994, Hogan, Hogan and Busch, 1984). Customer orientation behaviour of service employees has been found to have positive influence on customer satisfaction and emotional commitment (HenningThurau 2004). In this study, extent of service orientation behaviour of service employees in 1 to 3 star hotels was found to be unsatisfactory. Low level of customer orientation behaviour implies that service employees are performing below expectation.

\section{CONCLUSION}

One conclusion that can be drawn is that employees of the 1 and 2-star hotels were less professional than those of them in the 3 to 5 -star hotels. Employees at the $1 \& 2$-star hotels perform less emotional labour than those in the 3 to 5 -star hotels, yet, they experience more emotional dissonance and emotional exhaustion; because they use surface acting more often than deep acting. Based on the low levels of emotional self efficacy, perceived job knowledge and service orientation behaviour, it is concluded that the service quality is below expectation/average, particularly in 1 to 3 star hotels. The overall picture is that customers' experience with service employees during service interactions is not of superior quality. In all the variables studied, 5-star hotels were rated better than the others. It also concluded that emotional labour has not received adequate attention as a critical factor in quality service delivery.

\section{RECOMMENDATIONS}

Findings in this research have practical implications on internal marketing and human resources management systems. The service employees should be adequately trained in terms of how to behave during service interactions with customers and how to cope with the difficulties associated with this type of job. Therefore, hotel organizations should re-examine and redesign their internal marketing and human resources practices to incorporate emotional labour into their staff selection and training to enhance self efficacy and job knowledge. 


\section{REFERENCES}

[1] Abraham, R. (1998). Emotional Dissonance in Organizations. Antecedents, Consequences, and Moderators, Generic, Social, and General Psychology Monographs, 124(2).

[2] Adeyemo, D.A., and Ogunyemi, B. (2008).Emotional Intelligence and Self -Efficacy as Predictors of Occupational Stress among Academic Staff in a Nigerian University. $h t t p / / w w w . l e a d i n g t o d a y$. org.

[3] Ashforth, B.E. and Humphrey, R.H. (1993), Emotional labour in service roles: The Influence of Identity. Academy of Management Review, Vol. 18(1).

[4] Bandura, A. (2000). Cultivate Self-Efficacy for Personal and Organization Effectiveness In E.A. Locke (Ed.) Handbook of Principles of Organizational Behaviour. Oxford, U.K.

[5] Bitner, M.; Booms, B. and Tetreantt, M. (1990). The Service Encounter, Diagonosing Favourable and Unfavourable Incidents. Journal of Marketing, Vol. 54.

[6] Brotheridge, C.M., and Grandey, A.A. (2002), Emotional Labour and Burnout: Comparing Two Perspectives of "people work". Journal of Vocational Behaviour, Vol. 60. www.personal.psu. $e d u$.

[7] Brotheridge, C.M. and Lee, R.T. (2003), Development and Validation of the Emotional Labour Scale. Journal of occupational and organizational Psychology, Vol. 76.

[8] Caldwell, D.F. and O"Reilly, C.A. (1982), Boundary Spanning and Individual Performance. The Impact of Self-monitoring. Journal of Applied Psychological, 67(1).

[9] Cavelzani, A., Esposito, M. and Villamira, M. (2009), Emotional Intelligence and Hotel Business. University of Milan. Alessandro.cavelzazi@ium.it.

[10] Chu, K.H. (2002). The Effects of Emotional Labour on Employee work outcome.

[11] Virginia Polytechnic Institute and State University, U.S.A.

[12] Chu K.H.L. and Murrmann, S.K. (2006). Development and Validation of the hospitality Emotional Labour scale. Tourism Management, Vol.27(6).

[13] Cran, D.J. (1994). Towards Validation of the Service Orientation Construct. The Service Industry Journal. Vol. 14.

[14] De Witt, T. Liu, Y. (2002). The Customer Orientation - Loyalty Model: In W.J.

[15] Kehoe and J.H. Lindgren Jr. AMA Summer education Conference, Chicago.

[16] Dieffendorff, J., Croyle, M., and Gosserand, R. (2005), The Dimensionality and Antecedents, of Emotional Labour Strategies. Journal of Vocational Behaviour, Vol. 66.

[17] Enz, C., and Singuaw Jr. (2000), Best Practices in Service Quality. Cornell Hotel and Restaurant Administration Quarterly, Vol. 41(5). www.hotelschool.cornel.edu.

[18] Friedman, H.S., Miller-Herringer, T. (1991), Nonverbal display of emotions in

[19] Public and in private, self-monitoring, personality, and expressive cues. Journal of Personality and social Psychology, Vol. 61(5).

[20] Gay, L.R. (1996). Educational Researcy: Competencies for Analysis and Application. Ohio, U.S.A., Charles E. Merril Publishing Inc.

[21] Gibson, J.L., Ivan Cenvich, J.M. and Donelly Jr., J.H. (1994). Organizations: Structure and Process. $8^{\text {th }}$ edition, Illinois, Richard D. Irwin Inc.

[22] Gliem, J.A. and Gliem, R.E. (2003). Calculating, Interpreting, and Reporting Cronbach's Alpha Reliability Coefficient for Likert-Type Scales. 2003 Midwest Research to Practice Conference in Adult, Continuing and Community Education. Gliem2@osu.edu or gliem.1@osu.edu. 
[23] Grandey, A.A. (2000), Emotion Regulation in the workplace: A New Way to Conceptualize Emotional Labour. Journal of Occupational Health Psychology, Vol. 5(1). www.phd.scripts.psu

[24] Grandey, A.A., Dickter, D.N. and Sin, H.P. (2004), The Customer is not always Right: Customer aggression and emotion regulation of service employees. Journal of Organizational Behaviour, Vol. 25(3).

[25] Guy, M.E., Newman, M.A. and Mastracci, S.H. (2008), Emotional Labour: Putting the service in public service. New York, M.E. Sharpe, Lc.

[26] Gwinner, K.P., Meuler, K.L. (2001). A Comparison of attitude, Personality and Knowledge, Predictors of Service oriented-organization citizenship Behaviour. Journal of Applied Psychology. Vol. 86.

[27] Hall, S. (2010). How to use the Likert Scale in Statistical Analysis. Ehow.com; http://www.ehow. com.

[28] Hogan, J.R., Hogan, C. and Busch, C.M. (1984). How to Measure Service Orientation. Journal of Applied Psychology. Vol. 69.

[29] Hoschschild, A.R. (1983), The Managed Heart Communication of Human Feeeling Berkeley University of California Press.

[30] Jayawardhena, C., Farrel, A.M. and Sharma, A. (2009). The Impact of Employees Customer Orientation and Service Evaluation. Loughborough University, Business School, U.K. e-mail AMF.farrel@L.boro.ac.

[31] Johnson, H.M. (2004). The Story Behind Service with A Smile: The Effect of Emotional Labour on job satisfaction, Emotional Exhaustion, and Affective - well-being. A Thesis for Master of Arts. University of South Florida. U.S.A.

[32] Kennedy, J.M.C. (2008). Customer Rage, Emotions, Expressions and Behaviours. www.anzmac 2008.org.

[33] Kotler, P., Bowen, J.T. and Makens, J.C. (2006), Marketing for Hospitality and Tourism. $4^{\text {th }}$ edition. New Jersey, Pearson, Prentice Hall.

[34] Kruml, S.M. and Geddes, D. (2000), Catching fire without burning out, is there an ideal way to perform emotional labour? Emotions in the workplace. Westport, Quorum Books.

[35] Lee, D. (2010). How Employee Emotions Affect Your Organization's Ability to Compete. Reprinted from Human Resource Today, Articles and Reports - 2010.

[36] Maslach, G., and Jackson, S.E (1986), Maslach Burnout Inventory: Manual $2^{\text {nd }}$ ed. Palo Alto, California. Consulting Psychologists Press.

[37] Morris, J.A. and Feldman, D.C. (1997), Managing emotions in the Workplace. Journal of Managerial Issues, 9(3). www.questia.com.

[38] Nairing, G., Briet, M., and Brouwers, A. (2007). Validation of the Dutch Questionnaire on Emotional labour (D-QEL) in Nurses and Teachers.

[39] Psychosocial Resources in Human Services work. Gerard.naring@ ou.nl

[40] Noor, N.A.H., (2005). Individual Factors that Predict Customer-Orientation Behaviour of Malaysian Life Insurance Agents. Journal of Pengurusian. Vol. 24.

[41] Ogbuoshi, L. (2006). Research methodology and Thesis Writing. Enugu. Linco Enterprises

[42] Okeke, A.O. (1995). Foundation Statistics for Business Decisions. Enugu. Hig Mega System LTD.

[43] Onunkwo, G.I.N. (2002). Fundamentals of Educational Measurement and Evaluation. Owerri, Cape Publishers International Limited. 
[44] Pajera, F. (1994). The Role of Self-Efficacy. Paper presented at the Annual Meeting of the American Educational Research Association. New York.

[45] Peccei, R. and Rosenthal, P. (2001). Delivering Customer-Oriented Behaviour through Empowerment: An Empirical Test of HRM Assumptions. Journal of Management Studies, $38(6)$.

[46] Rahim, M. and Psenicka, G. (2002). A model of emotional Intelligence and conflict management strategies: A study of seven countries. The International Journal Organizational Analysis, 10(4).

[47] Russel, B. A., and Eisenberg, J. (2010). The role of cognition and attitude in driving behavior: Elaborating on Affective Event Theory (AET). University

[48] College , Dublin. Brona.russel@ucd.ie. $7^{\text {th }}$ International Conference on Emotion and Work life. Canada, August 2010.

[49] Snyder, M. (1974). Self-monitoring of expressive behaviour. Journal of Personality and social psychology. Vol. 30.

[50] Spiro, R.L., Weitz, B. (1990). Adaptive Selling Conceptualization, Measurement and homological validity. Journal of Marketing Research, Vol. 28.

[51] Susskind, A.M., Kacmar, K.M., and Borchgrevink, C.P. (2003). Customer Service Providers Attitudes Relating to Customer Service and Customer Satisfaction in the Customer Service Exchange. Journal of Applied Psychology, Vol. 88(1).

[52] Interaction and Emotional Labour in A Canadian Downtown Hotel; Just Labour. A Canadian Journal of work and Society, Vol. 10.

[53] Wang, G., Selbert, S. and Boles, T.L. (2010).Synthesizing what we know and looking ahead A meta Analytical Review of thirty years of emotional labour research. $7^{\text {th }}$ International Conference on Emotion and work life. gangwang@uiowa.edu

[54] Weiss, H. and Cropanzano, R. (1996). Affective events theory: A theoretical discussion of the structure, causes, and consequences of affective experience at work. Research in organizational Behaviour, Vol. 181.

[55] Wharton, A.S. (2009). The Sociology of emotional labour. Annual Review of Sociology. www.soc.annualreview.org.

[56] Wing, L. Yuanyuan, H. and Ziguang, C. (2010). Why need someone who fits to serve?: Person-job-fit, customer desirability, and emotional labour. $7^{\text {th }} \quad$ International Conference on emotion and Work life. Canada, Aug. 2010

[57] Wong, A. (2004). The Role of Emotional Satisfaction in Service encounters._e-EmeraldManaging Service Quality, Vol. 14(5).

[58] Wu, M.H., Yuan, Y.H. (2010).Research on the influence of Emotional Labour strategy used by public transportation Employee on service satisfaction. $7^{\text {th }}$ International Conference on Emotion and work life. Canada.

[59] Yoon, S. and Hyunsuk Suh (2004). Ensuring IT Consulting SERQUAQL and User Satisfaction. Information System Frontier. Vol. 6(4).

[60] Zapf, D. Vogt, C., Seifert, C., Mertini, H., Isic, A. (1999). Emotion work as source of stress: The concept and development of an instrument. European Journal of work and organizational Psychology, Vol. 8. www.igentaconnect.com.

\section{APPENDIX}

Questionnaire Items
A. Personal Efficacy. $\alpha=.84$
1. I am good at getting people calm down 
2. I do not worry about other people's/ customers' problem.

3. I have good understanding of my own feelings/emotions.

4. When somebody is angry I will not know by looking at him.

5. I cannot control my temper most times.

6. I help co-workers deal with stresses and difficulties at work.

7. I try to actually feel the emotion that I must display.

B. Customer-Service Orientation Behaviour. $\alpha=.83$

1. I make extra effort to meet customers' needs.

2. I don't smile at customer when they annoy me during service interaction.

3. My relationship with customer is not important to me.

4. I try to avoid unhappy customers.

5. I often make suggestions about how to improve customer service.

6. Sometimes I argue with customers.

7. I cannot go out of my way to help difficult customers.

C. Emotional Labour Perceived Job Knowledge. $\alpha=.87$

1. My job requires me to be nice to customers no matter how they treat me

2. My job requires that I manage customers' feelings/emotions.

3. I don't smile at customers when they annoy me.

4. My job requires me to remain calm and cheerful to customers no matter my situation./ matter how they treat me.

5. I don't hide negative feelings when a customer annoys me.

6. My work requires that I provide comfort to people/customer who are in crises.

7. My job involves managing feelings/emotions as critical aspect of my job. 